\title{
Receptor conversion in breast cancer patients with liver metastases after hepatectomy might affect survival
}

\author{
Kadri Altundag ${ }^{1}$ (D) \\ Received: 24 February 2018 / Accepted: 16 March 2018 / Published online: 20 March 2018 \\ ○) Springer Science+Business Media, LLC, part of Springer Nature 2018
}

\section{Dear Editor,}

I want to congratulate Ruiz and colleagues for their article [1] in which they evaluated survival in a select group of breast cancer liver metastases (BCLM) patients after hepatectomy. Patients who survived $<5$ years were compared to those who survived $\geq 5$ years from first diagnosis of hepatic metastases. Significant differences between patient groups ( $<5$ vs. $\geq 5$ years) were mean time interval between primary tumor and hepatic metastases diagnosis (50 vs. 43 months), mean number of resected tumors ( $3 \mathrm{vs} .2$ ), positive estrogen receptors (54\% vs. $79 \%$ ), microscopic lymphatic invasion (65\% vs. $34 \%$ ), vascular invasion (63\% vs. $37 \%$ ), hormonal therapy after resection (34\% vs. $74 \%)$, number of recurrence ( $40 \%$ vs. $65 \%)$, and repeat hepatectomy ( $1 \%$ vs. $42 \%)$, respectively. However, authors did not give information about discordance of immunohistochemical receptor status between primary and metastatic tumor. A change of estrogen receptor (ER), progesterone receptor (PR), and HER2 status in distant metastases has frequently been reported. Recent metaanalysis including 39 studies assessing receptor conversion from primary breast tumors to paired distant breast cancer metastases showed that negative to positive conversion percentages were $21.5,15.9$, and $9.5 \%$ for ER, PR, and HER2 [2]. Therefore, these patients might have a chance to use targeted endocrine and anti-HER-2 therapies which in turn might increase survival rate. The impact of receptor conversion on survival is not known in breast cancer patients with liver metastases and needs to be determined in large prospective studies.

Acknowledgement The author has not received any grants.

\section{Compliance with ethical standards}

Conflicts of interest I have no conflict of interest to declare.

Ethical approval My manuscript complies with the Ethical Rules applicable for this journal.

Human and animal rights This article does not contain any studies with human participants or animals performed by any of the authors.

\section{References}

1. Abraham J, Caldera H, Coleman R, Elias A, Goetz MP, Kittaneh M, Lower E, Mahtani R, Terry Mamounas E, Pegram M, Rugo H, Schwartzberg L, Traina T, Vogel C (2018) Endocrine therapy and related issues in hormone receptor-positive early breast cancer: a roundtable discussion by the breast cancer therapy expert group (BCTEG). Breast Cancer Res Treat. https://doi.org/10.1007/s1054 9-018-4662-9

2. Schrijver WAME, Suijkerbuijk KPM, van Gils CH et al (2018) Receptor conversion in distant breast cancer metastases: a systematic review and meta-analysis. J Natl Cancer Inst. https://doi. org/10.1093/jnci/djx273
Kadri Altundag

altundag66@yahoo.com

1 MKA Breast Cancer Clinic, Tepe Prime, 06800 Ankara, Turkey 